\title{
CHANGES IN PHYSICO-CHEMICAL PARAMETERS DURING FORCED-AERATION STATIC-PILE CO-COMPOSTING OF CATTLE MANURE WITH CALCIUM CYANAMIDE
}

\author{
Huasai Simujide ${ }^{a}$, Chen Aorigele ${ }^{a}$, Chun-Jie Wang ${ }^{b}$, Jun-E Yuc ${ }^{c}$, Bai Manda ${ }^{a}$, Ma Lina ${ }^{d}$ \\ ${ }^{a}$ College of Animal Science, Inner Mongolia Agricultural University, 010018 Hohhot, P. R. China \\ ${ }^{b}$ College of Veterinary Medicine, Inner Mongolia Agricultural University, 010018 Hohhot, P. R. China \\ ' Ulanqab Vocational College, 012000 Ulanqab, P. R. China \\ ${ }^{d}$ College of Life Sciences, Inner Mongolia Agricultural University, 010018 Hohhot, P. R. China
}

Submitted 08 Mar 2013; accepted 03 Oct 2013

\begin{abstract}
The goal of this research was to determine the effect of $\mathrm{CaCN}_{2}$ addition into manure mixed with sawdust on the composting process under forced-aeration static condition, especially on nitrogen $(\mathrm{N})$. The changes in the physical and chemical parameters over the entire composting period were evaluated. The profile of temperature, $\mathrm{pH}$, and $\mathrm{NO}_{3}{ }^{-} \mathrm{N}$ was improved in the piles mixed with $2 \%, 3 \%$ and $4 \% \mathrm{CaCN}_{2}$ (the test piles). The $\mathrm{NH}_{4}^{+}{ }^{-} \mathrm{N}$ met the limit value accepted for mature compost. Finally, the additive contents of not less than $2 \%$ but not more than $3 \%$ in $\mathrm{CaCN}_{2} \mathrm{were}$ recommended for this system based upon a comprehensive evaluation of the measured parameters.
\end{abstract}

Keywords: nitrogen, composting, manure, waste management technologies.

Reference to this paper should be made as follows: Simujide, H.; Aorigele, C.; Wang, C.-J.; Yu, J.-E.; Manda, B.; Lina, M. 2014. Changes in physico-chemical parameters during forced-aeration static-pile co-composting of cattle manure with calcium cyanamide, Journal of Environmental Engineering and Landscape Management 22(02): 125-131. http://dx.doi.org/10.3846/16486897.2013.852557

\section{Introduction}

Composting is a low-cost, effective and natural way of recycling organic materials, and it is included in sustainable agriculture and recommended for organic agriculture (Peigné, Girardin 2004). Composting has been shown to have some advantages, including pathogen suppression, weed seed killing and improvement of pesticide degradation (Dorahy et al. 2009; Karanasios et al. 2010), and its end products (composts) have been used as soil amendments due to their high concentration in organic matter (Ohsowski et al. 2012). Moreover, compost application in soil has been reported to reduce losses of N (Kelln et al. 2012). Despite these benefits, composting also can have several disadvantages. Several studies demonstrated that nutrients would be lost during composting (Venglovsky et al. 2011; Webber et al. 2009) and possible odors associated with composting would be generated (Li et al. 2008; Hanajima et al. 2010). Additionally, nutrient losses are an agronomic problem for organic farmers because they attempt to compensate for $\mathrm{N}$ scarce organic farms by their compost (Peigné, Girardin 2004). One of the nutrient losses during composting is $\mathrm{N}$ which is mainly lost as ammonia $\left(\mathrm{NH}_{3}\right)$ but may also as $\mathrm{N}_{2}, \mathrm{~N}_{2} \mathrm{O}$ and $\mathrm{NO}_{\mathrm{x}}$ (Bueno et al. 2009; Velasco-Velasco et al. 2011). Fukumoto and Inubushi (2009) noted that most of the $\mathrm{N}$ losses resulted from $\mathrm{NH}_{3}$ emission which was $9.5 \%$ of the initial total $\mathrm{N}(\mathrm{T}-\mathrm{N})$ during active composting of swine manure, when total $\mathrm{N}_{2} \mathrm{O}$ emissions were $9.3 \%$ of $\mathrm{T}-\mathrm{N}$, and total $\mathrm{N}$ losses were $27.8 \%$ of the initial $\mathrm{T}-\mathrm{N}$ which was markedly greater than the sum total of $\mathrm{NH}_{3}$ and $\mathrm{N}_{2} \mathrm{O}$. The $\mathrm{N}$ losses during composting can be influenced by several factors including temperature, $\mathrm{pH}, \mathrm{C} / \mathrm{N}$ ratio, and turning (Parkinson et al. 2004; Bueno et al. 2009).

Calcium cyanamide $\left(\mathrm{CaCN}_{2}\right)$ is an environmentally friendly $\mathrm{N}$ fertilizer with pesticide effects (Shi et al. 2009). And our previous studies showed that manure composting would quickly reach the sanitary standard and the quality of the composting products would be improved with the

Corresponding author: Chen Aorigele

E-mail: aori6009@163.com 
addition of $\mathrm{CaCN}_{2}$ (Simujide et al. 2012ab). Overall, these studies indicated the possibility of use of $\mathrm{CaCN}_{2}$ as an amendment during manure composting to improve composting efficiency. However, $\mathrm{N}$ fate during composting of this kind of compostable mixtures had not been evaluated. Therefore, the aim of this study was to evaluate the effect of $\mathrm{CaCN}_{2}$ addition on the changes in the physico-chemical parameters during manure composting, paying special attention to the evolution of $\mathrm{N}$, which will provide further information about the feasibility of selection of $\mathrm{CaCN}_{2}$ for composting.

\section{Materials and methods}

\subsection{Experimental design}

The experiment was carried out for $63 \mathrm{~d}$ from 21 April to 23 October 2012. Fresh manure of apparently healthy dairy cows from a 900-cow dairy farm was collected and mixed with sawdust (bulking agent) at a ratio of 4:1. Composting was conducted on a concrete apron, subdivided into four separate compartments, each with floor dimensions $50 \times 50 \mathrm{~cm}$. Compartments were isolated from each other by $40 \mathrm{~cm}$ high walls, and were all roofed. An iron screen mesh was installed about $10 \mathrm{~cm}$ above the reactor bottom to segregate the compost pile from the aeration channel. Sawdust was laid $2 \mathrm{~cm}$ thick over the iron screen mesh to distribute air equally, and air was blown to the piles using air pumps (one pump for one pile). Forcedaeration was conducted intermittently every day from the beginning of the composting process to $35 \mathrm{~d}$, and then the piles were turned once a week. In addition, the air supply was enriched by turning of piles after each sampling. Compost piles contained about $25 \mathrm{~kg}$ compostable mixtures per compartment at the beginning of the experiment, and were maintained in a roughly conical shape during composting. The piles were classified into three test piles (test I, test II and test III) and control pile. Solid $\mathrm{CaCN}_{2}$ was respectively mixed with test I, test II and test III at a rate of $2 \%, 3 \%$ and $4 \%$ by weight, while was not added into the control pile. Compost samples in duplicate were collected from each pile by using five-spot analyses at days $0,4,7,14,21,28,35,42,56$, and 63 for the analysis of different parameters. The characteristics of the composting materials are shown in Table 1.

Table 1. Characteristics of composting materials

\begin{tabular}{lccc}
\hline & Fresh manure & Sawdust & $\mathrm{CaCN}_{2}$ \\
\hline $\begin{array}{l}\text { Moisture } \\
\text { content }(\%)^{\mathrm{a}}\end{array}$ & $81.42 \pm 0.52^{\mathrm{b}}$ & $7.95 \pm 0.44$ & - \\
$\mathrm{C}(\%)^{\mathrm{a}}$ & $33.80 \pm 1.60$ & $42.43 \pm 1.78$ & $1.71 \pm 0.97$ \\
$\mathrm{~N}(\%)^{\mathrm{a}}$ & $1.71 \pm 0.05$ & $0.25 \pm 0.01$ & $21.24 \pm 0.08$ \\
$\mathrm{C} / \mathrm{N}$ ratio & 19.78 & 168.43 & 0.08 \\
\hline
\end{tabular}

${ }^{\text {a }}$ On a wet weight basis; ${ }^{\text {b }}$ Standard deviation.

\subsection{Physico-chemical analysis}

Ambient temperature around the compost bins and the temperature within each pile were measured daily at 9:00 AM and 16:00 PM. Daily temperature of the pile was the average temperature of the top, middle and bottom layer in the two measurements. The moisture content of the samples was determined after oven drying at $105^{\circ} \mathrm{C}$ to a constant weight (Li 1983). The $\mathrm{pH}$ was determined by a Mettler-Toledo EL20 pH-meter (Mettler-Toledo international trading (Shanghai) Co., Ltd.). Total nitrogen $(\mathrm{T}-\mathrm{N})$ and total carbon $(\mathrm{T}-\mathrm{C})$ was respectively measured by kjeldahl method and $\mathrm{K}_{2} \mathrm{Cr}_{2} \mathrm{O}_{7}$ volumetric method ( $\mathrm{Li}$ 1983). The concentration of $\mathrm{NH}_{4}^{+}-\mathrm{N}$ was determined by extracting the sample with $10 \% \mathrm{NaCI}$ and the extracts were distillated (Nanjing Agricultural College 1980). Phenol-disulfonic acid colorimetric method was used to obtain the concentration of $\mathrm{NO}_{3}^{-}-\mathrm{N}$ (Nanjing Agricultural College 1980).

\subsection{Statistical analysis}

Three replicates were used for each analysis. Data were presented as the mean values of triplicates.

\section{Results and discussion}

\subsection{Temperature}

The goal of the temperature control during a composting process is to achieve to the greatest extent the harmlessness and stabilization of the compost materials after composting. Temperature changes reflect microbial activities of the compost pile and the state of the composting process. As shown in Fig. 1, all piles presented a change of temperature rise, temperature drop and maturation. The test piles reached their highest temperature $44.80^{\circ} \mathrm{C}$ at $13 \mathrm{~d}$ in test $\mathrm{I}, 55.00{ }^{\circ} \mathrm{C}$ at $11 \mathrm{~d}$ in test II and $52.00{ }^{\circ} \mathrm{C}$ at $14 \mathrm{~d}$ in test III, respectively, while the control pile recorded the maximum temperature $43.80^{\circ} \mathrm{C}$ at $1 \mathrm{~d}$. The result indicated that the time to reach the high temperatures during composting was delayed with the addition of $\mathrm{CaCN}_{2}$ resulting from the reduced porosity of the compost piles in the beginning. However, the maximum temperatures in the test piles were higher than the control pile, and the duration of the high temperatures was also longer in the former than in the latter. But generally, the duration time in all piles was not long enough by comparison with the results of others. The temperatures of 55 to $60^{\circ} \mathrm{C}$ for 7 to $14 \mathrm{~d}$ were regarded as the ideal temperatures for effective composting (Tang et al. 2004; Johannessen et al. 2005; Sylla et al. 2006). As for lower temperatures, 33.5 to $41.5^{\circ} \mathrm{C}$ for $7 \mathrm{~d}$ was reported to be enough for efficient inactivation of bacterial populations such as E. coli during composting (Larney et al. 2003). In other aspect, a number of factors always have an effect on the change of composting 
temperature, including the composition of the composting materials, composting method, and environmental condition, etc. (Changa et al. 2003; de Guardia et al. 2010; Tirado, Michel 2010). The short duration of the high temperatures in the present study were mainly caused by the long ventilation time at the first stage of composting and the poor insulating qualities of small masses of the piles.

\subsection{Moisture content}

Desirable moisture contents of mixtures at the beginning of composting fall within the range of from 40 to $65 \%$ with a preferred range of 50-60\% (Agnew, Leonard 2003; Trémier et al. 2009). Nevertheless, in fed-batch composting of household biowaste, the optimum moisture content was in the range $30-40 \%$, at which the microorganisms showed the highest protease activity (Narihiro et al. 2004a, b). And a successful composting with high initial moisture contents was also reported (Hanajima et al. 2006). So, the optimum moisture conditions during composting depend on the nature of the compostable materials. The initial moisture contents in this study were adjusted around $65 \%$. The moisture content in all piles, on the whole, exhibited a declining trend (Fig. 2). The mean moisture content of the test piles decreased from an initial value of $64.69 \%$ to a final value of $60.78 \%$ in test I, from $64.13 \%$ to $58.44 \%$ in test II and from $63.77 \%$ to $61.94 \%$ in test III, respectively. In the control pile, it was from $67.08 \%$ to $61.50 \%$. Among them, the evaporation of moisture was highest in test II, which was related to the longest duration of the high temperatures in it.

\section{3. $\mathrm{pH}$}

The $\mathrm{pH}$ in the test piles showed the same change that followed a first sharp decline and then stabilization trend, when it increased greatly at the first 4 days and then went to stabilize in the control pile (Fig. 3). As the additive content of $\mathrm{CaCN}_{2}$ increased, the $\mathrm{pH}$ increased accordingly. The mean $\mathrm{pH}$ went respectively from an initial value of $7.40,9.38,10.78$ and 11.61 to $7.41,7.71,8.47$ and 8.91 in the control pile, test I, test II and test III at the end of composting. And during the process, the $\mathrm{pH}$ was below 9 from $4 \mathrm{~d}$ in test I and from $14 \mathrm{~d}$ both in test II and test III, and then almost fluctuated between 8 and 9 which is considered to be the preferred range for a successful composting (Zeng et al. 2011). Comparatively, the $\mathrm{pH}$ in the control pile was in 8-9 from $4 \mathrm{~d}$ to $21 \mathrm{~d}$ and then decreased slowly and stabilized around 7.5. This is an acceptable condition but not the ideal one.

\section{4. $\mathrm{N}$ transformation}

Trends in percent $\mathrm{T}-\mathrm{N}$ were shown in Fig. 4. At the first stage of composting, the $\mathrm{T}-\mathrm{N}$ changed relatively little in

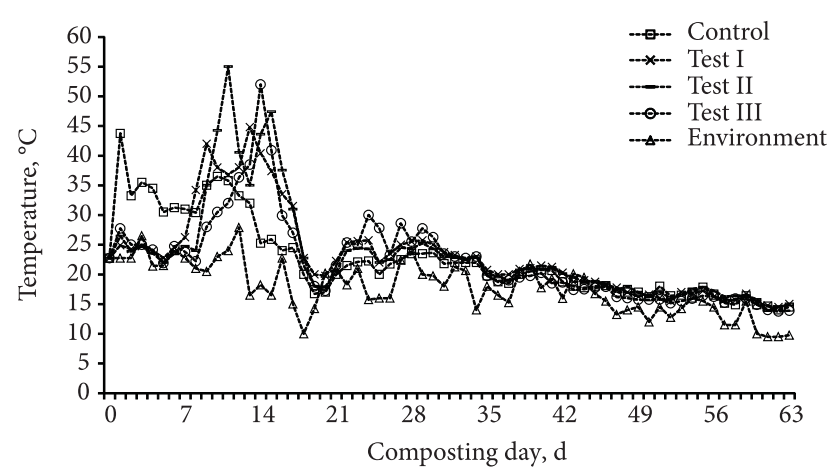

Fig. 1. The temperature profile during composting

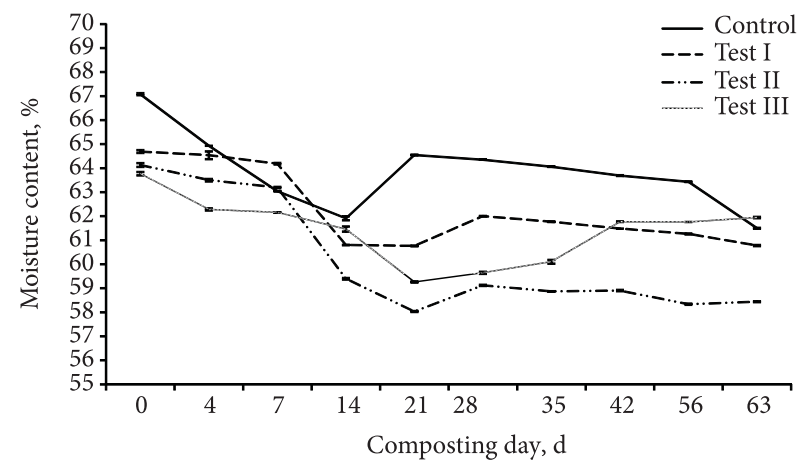

Fig. 2. The moisture content profile during composting

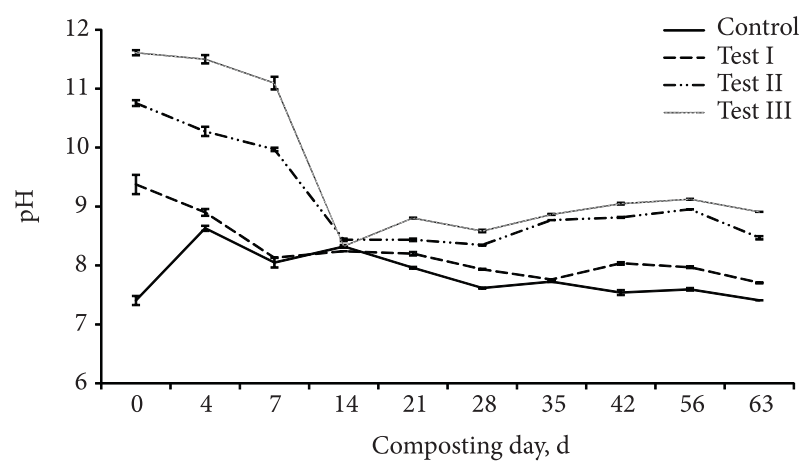

Fig. 3. The $\mathrm{pH}$ profile during composting

the control pile when decreased in the test piles, and then all began to increase. The decrease was due to the release of $\mathrm{N}$ in the form of $\mathrm{NH}_{3}$. With the composting time increasing, organic matters constantly decompose into $\mathrm{CO}_{2}$ and $\mathrm{H}_{2} \mathrm{O}$ and have a continuous loss, and the volume of the composting mixtures decreases accordingly. So, the T-N is condensed and its content always has a slight increase at the end of composting (Rihani et al. 2010). The percent T-N increased from an initial value of $0.89 \%, 2.02 \%$, $2.48 \%$ and $2.98 \%$ to $1.20 \%, 2.64 \%, 3.05 \%$ and $3.02 \%$ in the control pile, test I, test II and test III after $63 \mathrm{~d}$ composting that the increasing rate was $34.83 \%, 30.39 \%$, $22.98 \%$ and $1.34 \%$, respectively. This showed that the 


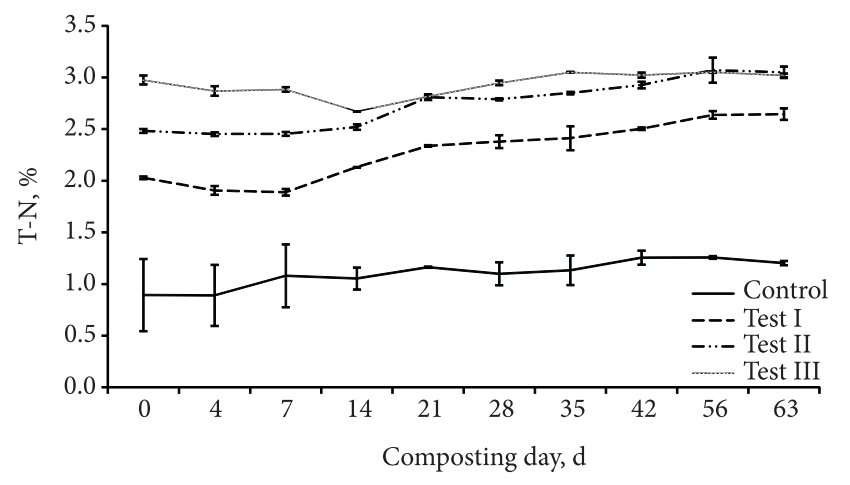

Fig. 4. The T-N profile during composting

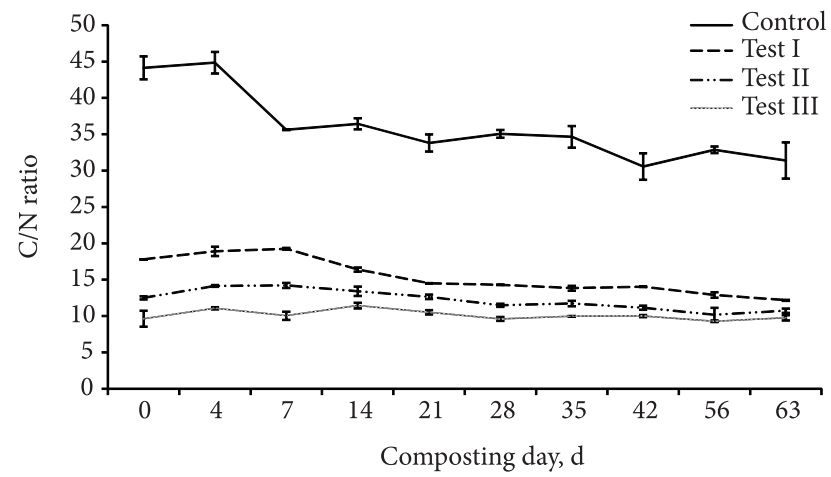

Fig. 5. The $\mathrm{C} / \mathrm{N}$ ratio profile during composting

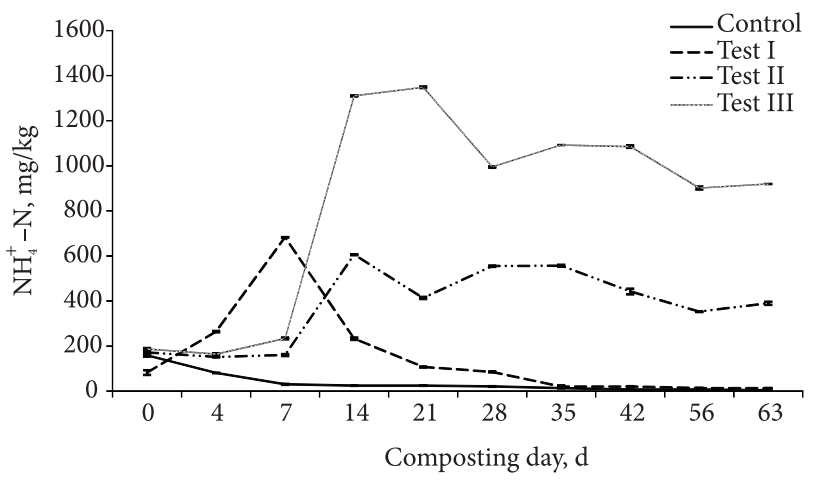

Fig. 6. The $\mathrm{NH}_{4}^{+}-\mathrm{N}$ profile during composting

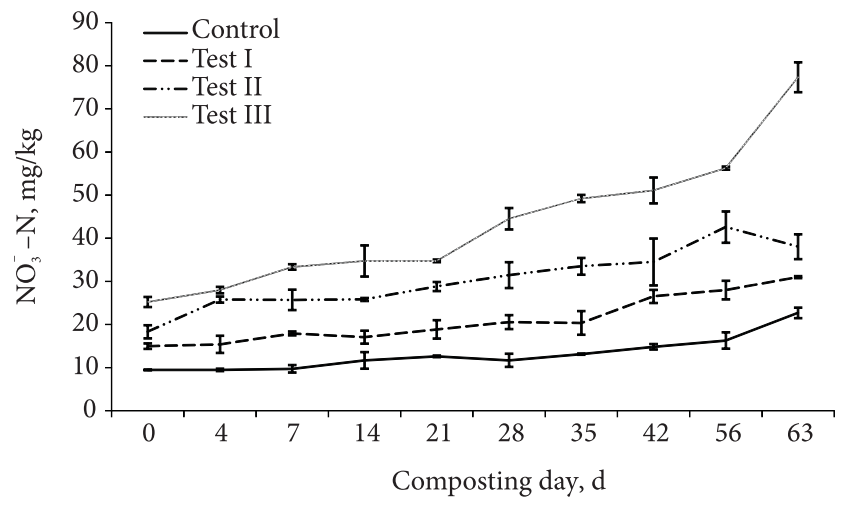

Fig. 7. The $\mathrm{NO}_{3}^{-}-\mathrm{N}$ profile during composting increasing rate of $\mathrm{T}-\mathrm{N}$ dropped with the increase of $\mathrm{CaCN}_{2}$ additive content, it was because the increase of additive content resulted in the decrease of $\mathrm{C} / \mathrm{N}$ ratio and when it went low, there was less $\mathrm{C}$ available for consumption, whereas $\mathrm{N}$ nutrients were relatively excess, causing a part of $\mathrm{N}$ to transform into ammoniacal $\mathrm{N}$ and have their volatilization losses. Paredes et al. (2000) found that during co-composting of olive mill wastewater with solid organic wastes, the high $\mathrm{N}$ losses through $\mathrm{NH}_{3}$ volatilization occurred in the mixtures which had low initial $\mathrm{C} / \mathrm{N}$ ratios (15.0-21.5), but it was reduced in the pile with the higher initial $\mathrm{C} / \mathrm{N}$ ratio (31.0). In the current study, the initial $\mathrm{C} / \mathrm{N}$ ratio was 44.13 in the control pile and 9.63-17.79 in the test piles. Then, it fell sharply in the control pile followed by test I and test II with a relatively little change in test III, before stabilizing and reaching values of 31.40 in the control pile and 9.75-12.17 in the test piles after the maturation phase (Fig. 5). The $\mathrm{C} / \mathrm{N}$ ratio was so low at the start in these piles that it would not be evaluated by the normal suggested levels.

The concentration of $\mathrm{NH}_{4}^{+}-\mathrm{N}$ always falls during the composting process (Paredes et al. 2000). However, different results have been found in some studies, for instance, Bueno et al. (2009) reported that the $\mathrm{NH}_{4}^{+}-\mathrm{N}$ concentrations increased significantly at the initial stage and then decreased during composting of trimming residues at different levels of moisture and particle size. As shown in Fig. 6, the $\mathrm{NH}_{4}^{+}-\mathrm{N}$ concentrations in all piles, although occurring at different times, increased significantly at the initial stage and reached their maximum level because of ammonification which is always associated with temperature increase and mineralization of organic $\mathrm{N}$ compounds (Bueno et al. 2009). Then, the $\mathrm{NH}_{4}{ }^{+}-\mathrm{N}$ concentrations decreased due to $\mathrm{NH}_{3}$ volatilization and immobilization by microorganisms (Bueno et al. 2009), indicating that the inhibitor was gradually eliminated as composting process continued. Except in test III, the $\mathrm{NH}_{4}{ }^{+}-\mathrm{N}$ contents in other piles were $<400 \mathrm{mg} / \mathrm{kg}$ at the end of composting, which is the maximum limit recommended for a mature compost. The $\mathrm{NO}_{3}{ }^{-}-\mathrm{N}$ contents showed a rising trend. During the thermophilic phase, lower increments were detected with respect to the mesophilic phase because of the inhibitory effect of $\mathrm{NH}_{3}$ and high temperature on the growth of nitrifying bacteria (Huang et al. 2004; Bueno et al. 2009). The addition of $\mathrm{N}$-rich $\mathrm{CaCN}_{2}$ produced the composts with higher $\mathrm{NO}_{3}{ }^{-}-\mathrm{N}$ concentrations than the control pile (Fig. 7).

\section{Conclusions}

1. The forced-aeration static-pile composting process of cattle manure mixed with $\mathrm{CaCN}_{2}$ is technically feasible, 
and it could be considered as an effective way to transform $\mathrm{N}$ and inactivate $E$. coli in manure.

2. The addition of $\mathrm{CaCN}_{2}$ delayed the time to reach the high temperatures during composting, but increased the high temperature levels and duration.

3. With addition of $\mathrm{CaCN}_{2}$, the $\mathrm{pH}$ evolution was improved; the final values of the $\mathrm{NH}_{4}^{+}-\mathrm{N}$ contents basically met the limit accepted for a mature compost; the final concentrations of $\mathrm{NO}_{3}{ }^{-}-\mathrm{N}$ were enhanced.

4. With a comprehensive assessment of the physico-chemical parameter values, the addition of not less than $2 \%$ but not more than $3 \% \mathrm{CaCN}_{2}$ was recommended.

\section{Acknowledgements}

We thank the National Natural Science Foundation of China (Nos. 31060318 and 31260570).

\section{References}

Agnew, J. M.; Leonard, J. J. 2003. The physical properties of compost, Compost Science \& Utilization 11(3): 238-264. http://dx.doi.org/10.1080/1065657X.2003.10702132

Bueno, P.; Yañez, R.; Caparrós, S.; Díaz, M. J. 2009. Evaluating environmental parameters for minimum ammonium losses during composting of trimming residues, Journal of the Air \& Waste Management Association 59(7): 790-800.

Changa, C. M.; Wang, P.; Watson, M. E.; Michel, F. C.; Hoitink, H. A. J. 2003. Assessment of the reliability of a commercial maturity test kit for composted manures, Compost Science \& Utilization 11(2): 127-145. http://dx.doi.org/10.1080/1065657X.2003.10702119

de Guardia, A.; Mallard, P.; Teglia, C.; Marin, A.; Le Pape, C.; Launay, M.; Benoist, J. C.; Petiot, C. 2010. Comparison of five organic wastes regarding their behaviour during composting: part 1, biodegradability, stabiliazation kinetics and temperature rise, Waste Management 30(3): 402-414. http://dx.doi.org/10.1016/j.wasman.2009.10.019

Dorahy, C. G.; Pirie, A. D.; McMaster, I.; Muirhead, L.; Pengelly, P.; Chan, K. Y.; Jackson, M.; Barchia, I. M. 2009. Environmental risk assessment of compost prepared from salvinia, Egeria densa, and alligator weed, Journal of Environmental Quality 38(4): 1483-1492. http://dx.doi.org/10.2134/jeq2007.0555

Fukumoto, Y.; Inubushi, K. 2009. Effect of nitrite accumulation on nitrous oxide emission and total nitrogen loss during swine manure composting, Soil Science and Plant Nutrition 55(3): 428-434.

http://dx.doi.org/10.1111/j.1747-0765.2009.00376.x

Hanajima, D.; Kuroda, K.; Fukumoto, Y.; Haga, K. 2006. Effect of addition of organic waste on reduction of Escherichia coli during cattle feces composting under high-moisture condition, Bioresource Technology 97(14): 1626-1630. http://dx.doi.org/10.1016/j.biortech.2005.07.034

Hanajima, D.; Kuroda, K.; Morishita, K.; Fujita, J.; Maeda, K.; Morioka, R. 2010. Key odor components responsible for the impact on olfactory sense during swine feces composting, Bioresource Technology 101(7): 2306-2310. http://dx.doi.org/10.1016/j.biortech.2009.11.026
Huang, G. F.; Wong, J. W.; Wu, Q. T.; Nagar, B. B. 2004. Effect of $\mathrm{C} / \mathrm{N}$ on composting of pig manure with sawdust, Waste Management 24(8): 805-813.

http://dx.doi.org/10.1016/j.wasman.2004.03.011

Johannessen, G. S.; James, C. E.; Allison, H. E.; Smith, D. L.; Suander, J. R.; McCarthy, A. J. 2005. Survival of a Shiga toxinencoding bacteriophage in a compost model, FEMS Microbiology Letters 245(2): 369-375.

http://dx.doi.org/10.1016/j.femsle.2005.03.031

Karanasios, E.; Tsiropoulos, N. G.; Karpouzas, D. G.; Ehaliotis, C. 2010. Degradation and adsorption of pesticides in compostbased biomixtures as potential substrates for biobeds in Southern Europe, Journal of Agricultural and Food Chemistry 58(16): 9147-9156. http://dx.doi.org/10.1021/jf1011853

Kelln, B.; Lardner, H.; Schoenau, J.; King, T. 2012. Effects of beef cow winter feeding systems, pen manure and compost on soil nitrogen and phosphorous amounts and distribution, soil density, and crop biomass, Nutrient Cycling in Agroecosystems 92(2): 183-194. http://dx.doi.org/10.1007/s10705-011-9480-y

Larney, F. J.; Yanke, L. J.; Miller, J. J.; McAllister, T. A. 2003. Fate of coliform bacteria in composted beef cattle feedlot manure, Journal of Environmental Quality 32(4): 1508-1515. http://dx.doi.org/10.2134/jeq2003.1508

Li, Q. K. 1983. Conventional methods of soil and agricultural chemistry analysis. Beijing: Science Press. 457 p. (in Chinese).

Li, X.; Zhang, R.; Pang, Y. 2008. Characteristics of dairy manure composting with rice straw, Bioresource Technology 99(2): 359-367. http://dx.doi.org/10.1016/j.biortech.2006.12.009

Nagao, N.; Watanabe, K.; Osa, S.; Matsuyama, T.; Kurosawa, N.; Toda, T. 2008. Bacterial community and decomposition rate in long term fed-batch composting using woodchip and Polyethylene terephthalate (PET) as bulking agents, World Journal of Microbiology \& Biotechnology 24(8): 1417-1424. http://dx.doi.org/10.1007/s11274-007-9625-y

Nanjing Agricultural College. 1980. Soil and agricultural chemistry analysis. Beijing: Agricultural Press. 395 p. (in Chinese).

Narihiro, T.; Abe, T.; Yamanaka, Y.; Hiraishi, A. 2004a. Microbial population dynamics during fed-batch operation of commercially available garbage composters, Applied Microbiology and Biotechnology 65(4): 488-495. http://dx.doi.org/10.1007/s00253-004-1629-Z

Narihiro, T.; Takebayashi, S.; Hiraishi, A. 2004b. Activity and phylogenetic composition of proteolytic bacteria in mesophilic fed-batch garbage composters, Microbes and Environment 19(4): 292-300. http://dx.doi.org/10.1264/jsme2.19.292

Ohsowski, B. M.; Klironomos, J. N.; Dunfield, K. E.; Hart, M. M. 2012. The potential of soil amendments for restoring severely disturbed grasslands, Applied Soil Ecology 60: 77-83. http://dx.doi.org/10.1016/j.apsoil.2012.02.006

Paredes, C.; Roig, A.; Bernd, M. P. 2000. Evolution of organic matter and nitrogen during co-composting of olive mill wastewater with solid organic wastes, Biology and Fertility of Soils 32(3): 222-227. http://dx.doi.org/10.1007/s003740000239

Parkinson, R.; Gibbs, P.; Burchett, S.; Misselbrook, T. 2004. Effect of turning regime and seasonal weather conditions on nitrogen and phosphorus losses during aerobic composting of cattle manure, Bioresource Technology 91(2): 171-178. http://dx.doi.org/10.1016/S0960-8524(03)00174-3 
Peigné, J.; Girardin, P. 2004. Environmental impacts of farmscale composting practices, Water Air and Soil Pollution 153(1-4): 45-68. http://dx.doi.org/10.1023/B:WATE.0000019932.04020.b6

Rihani, M.; Malamis, D.; Bihaoui, B.; Etahiri, S.; Loizidou, M.; Assobhei, O. 2010. In-vessel treatment of urban primary sludge by aerobic composting, Bioresource technology 101(15): 5988-5995. http://dx.doi.org/10.1016/j.biortech.2010.03.007

Shi, K.; Wang, L.; Zhou, Y. H.; Yu, Y. L.; Yu, J. Q. 2009. Effects of calcium cyanamide on soil microbial communities and $\mathrm{Fu}$ sarium oxysporum f. sp. Cucumberinum, Chemosphere 75(7): 872-877.

http://dx.doi.org/10.1016/j.chemosphere.2009.01.054

Simujide, H.; Aorigele, C.; Wang, C. J.; Manda, B.; Ma, L. N. 2012a. Effect of calcium cyanamide on pathogenic Escherichia coli during mesophilic composting and impact on composting process, Global Nest Journal 14(4): 460-467.

Simujide, H.; Aorigele, C.; Wang, C. J.; Manda, B.; Ma, L. N.; Wu, M. Y.; Li, Y.; Bai, T. R. G. 2012b. Reduction of foodborne pathogens during cattle manure composting with addition of calcium cyanamide, Journal of Environmental Engineering and Landscape Management 21(2): 77-84.

http://dx.doi.org/10.3846/16486897.2012.721373

Sylla, Y. B.; Kuroda, M.; Yamada, M.; Matsumoto, N. 2006. Feasibility study of a passive aeration reactor equipped with vertical pipes for compost stabilization of cow manure, Waste Management \& Research 24(5): 456-464. http://dx.doi.org/10.1177/0734242X06066429

Tang, J. C.; Kanamori, T.; Inoue, Y.; Yasuta, T.; Yoshida, S.; Katayama, A. 2004. Changes in the microbial community structure during thermophilic composting of manure as detected by the quinone profile method, Process Biochemistry 39(12): 1999-2006. http://dx.doi.org/10.1016/j.procbio.2003.09.029
Tirado, S. M.; Michel, F. C. 2010. Effects of turning frequency, windrow size and season on the production of dairy manure/ sawdust composts, Compost Science \& Utilization 18(2): 7080. http://dx.doi.org/10.1080/1065657X.2010.10736938

Trémier, A.; Teglia, C.; Barrington, S. 2009. Effect of initial physical characteristics on sludge compost performance, Bioresource Technology 100(15): 3751-3758.

http://dx.doi.org/10.1016/j.biortech.2009.01.009

Velasco-Velasco, J.; Parkinson, R.; Kuri, V. 2011. Ammonia emissions during vermicomposting of sheep manure, Bioresource Technology 102(23): 10959-10964.

http://dx.doi.org/10.1016/j.biortech.2011.09.047

Venglovsky, J.; Sasakova, N.; Gregová, G.; Lakticova, K.; Ondrasovicova, O.; Ondrasovic, M.; Köfer, J.; Schobesberger, H. 2011. Nitrogen loss during composting of poultry litter, in Animal Hygiene and Sustainable Livestock Production, Proceedings of the XV International Congress of the International Society for Animal Hygiene, 3-7 July, 2011, Vienna, Austria, Tribun EU, 1127-1129.

Webber, D. F.; Mickelson, S. K.; Richard, T. L.; Ahn, H. K. 2009. Effects of a livestock manure windrow composting site with a fly ash pad surface and vegetative filter strip buffers on sediment, nitrate, and phosphorus losses with runoff, Journal of Soil and Water Conservation 64(2): 163-171. http://dx.doi.org/10.2489/jswc.64.2.163

Yao, H. C. 2002. Veterinary Microbiology experiment guidance. Beijing: Chinese Agricultural Press. 128 p. (in Chinese).

Zeng, G.; Yu, Z.; Chen, Y.; Zhang, J.; Li, H.; Yu, M.; Zhao, M. 2011. Response of compost maturity and microbial community composition to pentachlorophenol (PCP)-contaminated soil during composting, Bioresource Technology 102(10): 5905-5911. http://dx.doi.org/10.1016/j.biortech.2011.02.088

Huasai SIMUJIDE. Works in College of Animal Science, Inner Mongolia Agricultural University. Number of publications: 16; participated in two conferences in China. Research interests include waste management technologies, air pollution, landscape management, veterinary microbiology.

Chen AORIGELE. Works in College of Animal Science, Inner Mongolia Agricultural University. Number of publications: 54; participated in 22 conferences in China. He has been awarded the following awards: Inner Mongolia Autonomous Region Science and Technology Progress Award twice, Inner Mongolia Autonomous Region Youth Science and Technology Award once. He has been the Executive Director of Straw Resources Utilization Branch of Chinese Association of Agricultural Science Societies; the Executive Director of Inner Mongolia Dairy Association; the Vice General Secretary of Inner Mongolia Association of Animal Science; the Deputy Director of Inner Mongolia Breeding Professional Committee; the member of Japanese Society of Animal Science, Japanese Society of Grassland Science, Japanese Society of Application of Animal Behavior. Research interests include waste management technologies, air pollution, landscape management, environmental management.

Chun-Jie WANG. Works in College of Veterinary Medicine, Inner Mongolia Agricultural University. Number of publications: 59; has participated in 18 conferences in China. He has been awarded the following awards: Inner Mongolia Autonomous Region "321 talents project" the second level people, Inner Mongolia Autonomous Region Department of Education "111 talents project" the third level people. He has been the Council Member of Chinese Association of Animal Physiology, Northern China Association of Veterinary Pathology; the member of Chinese Association of Veterinary Pathology; the premium member of Chinese Association of Animal Science and Veterinary Medicine. Research interests include waste management technologies, landscape management, environmental management, medical microbiology.

Jun-E YU. Works in Ulanqab Vocational College. Number of publications: 3; has participated in one conference in China. Research interests include waste management technologies, air pollution, landscape management. 
Bai MANDA. Works in College of Animal Science, Inner Mongolia Agricultural University. Number of publications: 5; has participated in two conferences in China. Research interests include waste management technologies, air pollution, landscape management.

Ma LINA. Works in College of Life Sciences, Inner Mongolia Agricultural University. Number of publications: 5; has participated in two conferences in China. Research interests include waste management technologies, air pollution, landscape management, food and fermentation engineering. 